O. DARIUSZ BOREK OCarm

Wydział Prawa Kanonicznego

Uniwersytetu Kardynała Stefana Wyszyńskiego w Warszawie

ORCID: 0000-0002-9975-4309

\title{
PRZEDAWNIENIE SKARG I DZIAŁAŃ Z TYTUŁU NARUSZEŃ BĘDĄCYCH PRZESTĘPSTWAMI KANONICZNYMI
}

Treść: Wstęp. - 1. Przedawnienie. - 1.1. Zagadnienia wstępne. - 1.2. Pojęcia i elementy zasadnicze. - 2. Przedawnienie w ramach odpowiedzialności karnej. - 2.1. Wymierzanie i wykonanie kary. - 2.2. Deklarowanie kary. - 2.3. Przestępstwa zastrzeżone dla Kongregacji Nauki Wiary. - 3. Przedawnienie w ramach odpowiedzialności cywilnej i dyscyplinarnej. - 3.1. Skarga o naprawienie szkód. - 3.2. Wydalenie z instytutu zakonnego. - Wnioski.

\section{Wstęp}

Popełnienie naruszeń wyczerpujących znamiona przestępstwa kanonicznego pociąga lub może pociągać za sobą określone skutki karne i/lub pozakarne. Do skutków ściśle karnych należy zaliczyć możliwość pociągnięcia sprawcy do odpowiedzialności karnej. W tym celu Kodeks prawa kanonicznego z 1983 roku przewiduje właściwie dwa rodzaje skarg związanych z popełnionym przestępstwem': skargę

\footnotetext{
${ }^{1}$ Systemy państwowe, obok przedawnienia ścigania oraz wykonania kary, przewidują także przedawnienie wyrokowania, które polega na tym, że nie można wydać wyroku skazującego (chociażby już wszczęto proces), jeżeli od popełnienia przestępstwa minął okres przewidziany w ustawie. W prawie kanonicznym nie przewiduje się innego/oddzielnego czasu na przedawnienie wyrokowania.
} 
kryminalną (actio criminalis ${ }^{2}$ ) i skargę o wykonanie kary (actio ad poenam exsequendam ${ }^{3}$ ) inaczej skargę penalną lub karnąa ${ }^{4} \mathrm{Z}$ naruszenia będącego jednocześnie przestępstwem ${ }^{5}$ mogą wynikać także inne pozakarne skutki, przykładowo skarga o naprawienie szkód powstałych z popełnionego przestępstwa (actio ad damna reparanda $a^{6}$ ), deklarowanie przeszkody do święceńn ${ }^{7}$, czy wydalenie $\mathrm{z}$ instytutu zakonnego $^{8}$. Przedawnienie, będące przedmiotem obecnego artykułu, wiąże się zatem $\mathrm{z}$ różnymi możliwymi skutkami jakie pociąga za sobą fakt popełnienia naruszenia będącego przestępstwem kanonicznym.

Mając na uwadze różne konsekwencje, jakie mogą wynikać z tytułu naruszeń wyczerpujących znamiona przestępstwa kanonicznego, zasadne wydaje się ustalenie tego, co ulega przedawnieniu w związku z popełnionym przestępstwem kanonicznym. Próbując udzielić odpowiedzi na wyżej postawione pytanie, niezbędne wydaje się skoncentrowanie uwagi na następujących zagadnieniach: 1. Przedawnienie. 1.1. Zagadnienia wstępne. 1.2. Pojęcia i elementy zasadnicze. 2. Przedawnienie w ramach odpowiedzialności karnej. 2.1. Wymierzanie i wykonanie kary. 2.2. Deklarowanie kary. 2.3. Przestępstwa zastrzeżone dla Kongregacji Nauki Wiary. 3. Przedawnienie w ramach odpowiedzialności cywilnej i dyscyplinarnej. 3.1. Skarga o naprawienie szkód. 3.2. Wydalenie z instytutu zakonnego.

\section{Przedawnienie}

\subsection{Zagadnienia wstępne}

Przedawnienie na płaszczyźnie kanonicznego prawa karnego należy do tej grupy zagadnień, którym do niedawna poświęcano niewiele

\footnotetext{
${ }^{2}$ KPK/1983, kan. 1362; 1720; 1726.

${ }^{3}$ KPK/1983, kan. 1363.

${ }^{4}$ Por. J. SyryjCzy K, Sankcje w Kościele. Część ogólna. Komentarz, Warszawa 2008,

${ }^{5}$ Por. KPK/1983, kan. $1321 \$ 1$.

${ }^{6} \mathrm{KPK} / 1983$, kan. $1729 \$ 1$.

${ }^{7}$ KPK/1983, kan. 1044.

${ }^{8}$ KPK/1983, kan. 694; 695.
} s. 326. 
uwagi. Z pewnością wynikało to $\mathrm{z}$ tego, że w prawie kanonicznym aż do drugiej połowy dziewiętnastego wieku brakowało wyraźnych przepisów, które regulowałyby sprawę przedawnienia w prawie karnym. Dopiero bowiem w 1898 roku spotykamy się z wyraźnym przepisem odnoszącym się wprost do przedawnienia. Jest to dekret Kongregacji Biskupów i Zakonników z 21-22 marca 1898 roku wydany w tzw. sprawie lubelskiej ${ }^{9}$. Pewien zwrot zainteresowania zagadnieniami związanymi z przedawnieniem na płaszczyźnie kanonicznego prawa karnego można zauważyć w okresie obowiązywania Kodeksu z 1917 roku $^{10}$. Niemniej jednak także i w tym czasie trudno mówić o szerszym zainteresowaniu omawianym zagadnieniem. Z podobną sytuacją spotykamy się we współczesnej nauce prawa kanonicznego zajmującej się prawem karnym. W komentarzach i podręcznikach do niedawna spotykało się jedynie krótkie odniesienia do interesującego nas zagadnienia. Autorzy zwracali w nich uwagę na najistotniejsze

${ }^{9}$ Marian Myrcha w rozwoju instytucji przedawnienia karnego w prawie kanonicznym rozróżnia trzy okresy: 1 - do dekretu Lubelskiego; 2 - od dekretu Lubelskiego do Kodeksu prawa kanonicznego; 3 - Kodeks prawa kanonicznego. M. MrrchA, Prawo karne. Kara, tom II, Warszawa 1960, s. 782. Aktualnie należałoby jeszcze wyróżnić dwa okresy: 1 - Kodeks prawa kanonicznego z 1983 roku; 2 - Motu proprio Sacramentorum sanctitatis tutela z 2001 roku wraz z późniejszymi zmianami. Jak można zauważyć, punktem zwrotnym na etapie wyartykułowania odnośnych przepisów kościelnych w kwestii przedawnienia prawa ścigania i karania był tzw. dekret lubelski z 1898 roku, to znaczy Decyzja Kongregacji Biskupów i Zakonników z 8 marca 1898 roku, zatwierdzona przez Papieża, stanowiąca odpowiedź na pytanie Biskupa diecezji Lubelskiej dotycząca tego, czy przestępstwa cielesne duchownych ulegają przedawnieniu, a jeśli tak, to po upływie jakiego czasu: „I. An delicta carnis, a clericis commissa, aliqua praescriptione extinguantur; ita ut certo temporis spatio interiecto, in ea amplius neque inquiri, neque reos poena affici, sive ad instantiam privati accusatoris, sive as vindictam publicam seu ex officio fas sit? et quatenus affirmative II. Quinam annorum numerus requiratur ad hanc praescriptionem inducendam?", Sacra Congregatio Episcoporum et Regularium, Praescriptionis in causis criminalibus ecclesiasticis, Acta Sanctae Sedis 30 (1897-1898), s. 677-678, cały tekst odpowiedzi Kongregacji znajduje się na str. 677-698.

${ }^{10} \mathrm{~W}$ literaturze polskiej na szczególną uwagę zasługują następujące pozycje: S. Czajka, Przedawnienie w prawie karnem kanonicznem, Lublin 1934; M. MrRCHA, dz. cyt., s. 763-845. 
problemy związane z zagadnieniem przedawnienia ${ }^{11}$. Jak się wydaje, było to spowodowane w głównej mierze niewielką liczbą procesów karnych w Kościele. Taki stan rzeczy, to znaczy znikoma liczba procesów karnych, wynikał z tego, iż wymiar/deklarowanie kary w Kościele traktowano, zgodnie z założeniami ustawodawcy kodeksowego z 1983 roku, jako extrema ratio. Nie bez znaczenia pozostaje i to, że w praktyce przestępstwa zarezerwowane dla Kongregacji Nauki Wiary właściwie nie podlegały przedawnieniu. Sprawa stała się bardziej aktualna w związku z późniejszymi normami, dotyczącymi doniesień o przestępstwach nadużyć seksualnych popełnionych przez duchownych wiele lat wcześniej ${ }^{12}$. W ostatnim czasie można zaobserwować stopniowe ożywienie zainteresowania zagadnieniami związanymi $\mathrm{z}$ instytucją przedawnienia w kanonicznym prawie karnym ${ }^{13}$.

${ }^{11}$ Zob. T. Pawluk, Prawo kanoniczne według Kodeksu Jana Pawła II, t. 4, Olsztyn 2009, s. 119-122; B. WóJCiK-J. Krukowski-F. LempA, Komentarz do Kodeksu prawa kanonicznego, t. 4, Lublin 1987, s. 214-215; A.G. URRU, Punire per salvare. Il sistema penale nella Chiesa, Roma 2001, s. 175-179. Nieco więcej miejsca temu zagadnieniu poświęcił J. Syryjczyk w swojej książce, zob. J. Syry JCZY K, dz.cyt., s. 319-327.

${ }^{12}$ Zob. D.G. Astigueta, Delitti imprescrittibili nella Chiesa?, Periodica 101 (2012), s. 103-158; J. Llobell, Sull'interruzione e sulla sospensione della prescrizione dell'azione penale, Ius Ecclesiae 25 (2013), s. 641-661.

${ }^{13}$ Zob. D. Cito, La prescrizione in materia penale, w: Processo penale e tutela dei diritti nell'Ordinamento canonico, a cura di D. Cito, Milano 2005, s. 208-233; C.G. Renati, Prescription and derogation from prescription in sexual abuse of minors cases, The Jurist 67 (2007), s. 511-513; PH.J. BRown, Prescription and Statutes of Limitation, w: Canon Law Society of America, Proceedings of the Seventieth Annual Convention, Kansas City, Missouri, Washington 2008, s. 383-481; J.L. SÁnCHez Girón, Algunos interrogantes en la disciplina codicial sobre la prescripción de la acción criminal, w: Iustitia et Iudicium. Studi di diritto matrimoniale e processuale canonico in onore di Antoni Stankiewicz, a cura di Janusz Kowal e Joaquín Llobell, Vol. IV, Città del Vaticano 2010, s. 2167-2185; D.A. AstiguetA, dz. cyt., s. 103-158; J. Llobell, Sull'interruzione e sulla sospensione..., s. 641-661; M. SтокŁosA, Przedawnienie skargi kryminalnej w prawie kanonicznym, Prawo Kanoniczne 56 (2013) nr 4, s. 139-154; P. Skonieczny, Koncepcja przedawnienia kanonicznego. Uwagi prawnoporównawcze i teoretycznoprawne do kan. 197 KPK (kan. 1540 KKKW), ze szczególnym uwzględnieniem kanonizowanej ustawy polskiej, Prawo Kanonicze 56(2013) nr 1, s. 3-30; P. Skonieczny, Przesłanki przedawnienia kanonicznego ze 
Aktualne zainteresowanie tym zagadnieniem jest - jak się wydaje - efektem zmian i nowelizacji wprowadzonych w zakresie przestępstw zastrzeżonych dla Kongregacji Nauki Wiary, w sposób szczególny przestępstw przeciwko obyczajom, popełnionych przez duchownych z małoletnimi poniżej osiemnastego roku życia. Zarówno motu proprio papieża Jana Pawła II Sacramentorum sanctitatis tutela z 2001 roku $^{14}$, jak i późniejsze uzupełnienia i modyfikacje ${ }^{15}$, włącznie z tymi z 2010 roku $^{16}$, przyjmują zasadę przedawnienia skargi kryminalnej w przypadku przestępstw zastrzeżonych dla Kongregacji Nauki Wiary. Niemniej jednak już w niedługim czasie po promulgacji m.p. Sacramentorum sanctitatis tutela w 2001 roku, Kongregacja uzyskała możliwość interwencji w przypadku przestępstw tego rodzaju

szczególnym uwzględnieniem kanonizowanej ustawy cywilnej polskiej, Prawo Kanoniczne 57 (2014) nr 2, s. 91-128; D. Ciто, Questioni sulla prescrizione dell'azione criminale /art. 7 m.p. Sacramentrum sanctitatis tutle/, w: Quaderni di Ius Missionale a cura di Papale Claudio, Città del Vaticano 2016, s. 27-44; S. Paglialunga, La prescrizione nel diritto penale canonico, Periodica 107 (2018), s. 327-357.

${ }^{14}$ JoAnnes Paulus II, Litterae Apostolicae motu proprio datae quibus Normae de gravioribus delictis Congregationi pro Doctrina Fidei reservatis promulgantur, Sacramentorum Sanctitatis Tutela, 30 aprilis 2001, AAS 93 (2001), s. 737-739; Congregatio pro Doctrina Fidei, Epistula a Congregatione pro Doctrina Fidei missa ad totius Catholicae Ecclesiae Episcopos aliosquae Ordinarios et Hierarchos interesse habentes: de delictis gravioribus eidem Congregationi pro Doctrina Fidei reservatis, 18 maii 2001, AAS 93 (2001), s. 785-788. Dalej Normy, de gravioribus delictis z $2001 \mathrm{r}$.

${ }^{15}$ Chodzi o zmiany dokonane na mocy decyzji, jakie w okresie 7.11.2002-14.02.2003, podejmował papież Jan Paweł II, następnie zatwierdzone przez Benedykta XVI w dniu 6 maja 2005 roku, w celu dostosowania przepisów do wyzwań, przed jakimi stanął w owym okresie Kościół katolicki. Por. Congregatio pro Doctrina Fidei, Breve relazione circa le modifiche introdotte nelle Norme de gravioribus delictis riservato alla Conregazione per la Dottrina della Fede, 15 luglio 2010, AAS 102 (2010), s. 432-434. Zob. także, B.F. Pighin, Diritto penale canonico, Venezia 2008, s. 616-618; J. LlOBELL, Il giusto processo penale nella Chiesa e gli interventi (recenti) della Santa Sede, Archivio Giuridico 232 (2012) nr 2, s. 169-171.

${ }^{16}$ Congregatio pro Doctrina Fidei, Normae de delictis Congregationi pro Doctrina Fidei reservatis seu Normae de delictis contra fidem necnon de gravioribus delictis (21.05.2010), AAS 102 (2010), s. 419-434. Dalej Normy de delictis reservatis z 2010 r. 
nawet po upływie wielu lat ${ }^{17}$. Istnieje wiele przykładów skorzystania $\mathrm{z}$ tego uprawnienia, przede wszystkim w odniesieniu do duchownych dopuszczających się nadużyć seksualnych wobec osób małoletnich ${ }^{18}$. Z kolei w Normach z 2010 roku wyraźnie wspomina się o możliwości wszczęcia postępowania nawet po upływie czasu przedawnienia ${ }^{19}$. Należy zaznaczyć, że uchylenie przepisów dotyczących przedawnienia skargi kryminalnej w przypadku przestępstw zastrzeżonych dla Kongregacji Nauki Wiary powinno być czymś wyjątkowym, z zasady bowiem możliwość ich ścigania ulega przedawnieniu.

\subsection{Pojęcia i elementy zasadnicze}

Przedawnienie to następujące w wyniku upływu czasu nabycie/ utrata rzeczy lub praw, a także uwolnienia się od obowiązków/roszczeń $^{20}$. Zgodnie z powyższym, przedawnienie może polegać albo na zasiedzeniu praw, czyli na nabyciu prawa przez faktyczne jego wykonywanie, albo na przedawnieniu roszczeń, czyli uwolnieniu się od roszczeń czy obowiązków dlatego, że ich nie dochodzono ${ }^{21}$.

${ }^{17}$ W listopadzie 2002 roku Ojciec Święty udzielił Kongregacji Nauki Wiary upoważnienia do uchylenia przedawnienia w poszczególnych przypadkach na uzasadniony wniosek ze strony zainteresowanego biskupa. Zob. CH.J. SciclunA, Procedura e prassi presso la Congregazione per la Dottrina della Fede ai Delicta Graviora, w: Processo penale e tutela dei diritti nell'ordinamento canonico, pod red. D. Cito, Milano 2005, s. 284. Tekst wspominanych uprawnień nie został oficjalnie opublikowany, ale możemy go znaleźć w książce W.H. WoEstmen, Ecclesiastical Sanctions and the Penal Process. A Commentary on the Code of Canon Law, 2 ed., Ottawa 2003, s. 314-316.

${ }^{18}$ D. Cito, La prescrizione in materia penale..., s. 210 . Jak wynika z relacji Ch.J. Scicluna, promotora sprawiedliwości w Kongregacji Nauki Wiary, w latach 2001 - 2010 przekazano do Kongregacji Nauki Wiary około trzech tysięcy przypadków nadużyć seksualnych dokonanych przez duchownych w ostatnich pięćdziesięciu latach, a więc z okresu przekraczającego znacząco czas przedawnienia skargi kryminalnej. G. CuCCI - H. Zollner, Chiesa e pedofilia. Una ferita aperta. Un approccio psicologico-pastorale, Venezia 2010, s. 23.

${ }^{19}$ Zob. Normy de delictis reservatis z 2010 r., art. $7 \$ 1$.

${ }^{20}$ KPK/1983, kan. 197.

${ }^{21}$ Zob. P. Skonieczny, Koncepcja przedawnienia kanonicznego..., s. 3-30; tenże, Przesłanki przedawnienia kanonicznego..., s. 91-128. 
Jeśli chodzi o zasady związane z instytucją przedawnienia, to należy stwierdzić, że Kościół przyjmuje przedawnienie takie, jakie jest w ustawodawstwie cywilnym danego kraju, z zachowaniem wyjątków ustanowionych w kanonach tego Kodeksu ${ }^{22}$. Jeden $\mathrm{z}$ takich wyjątków jest przewidziany w kan. 198: „Nulla valet praescriptio, nisi bona fide nitatur, non solum initio, sed toto decursu temporis ad praescriptionem requisiti, salvo praescripto can. 1362". Jak wynika z zacytowanego kanonu, w systemie prawnym kanonicznym dobra wiara z zasady jest konieczna przez cały okres wymagany do zasiedzenia/przedawnienia. W dobrej wierze znajduje się osoba, która jest rzetelnie przekonana, że jej działanie jest zgodne z prawem. Wspomniane rzetelne przekonanie, to przekonanie rzeczywiste, pozbawione wątpliwości i nie oparte na zawinionym błędzie lub zawinionej nieznajomości ${ }^{23}$. Wymóg dobrej wiary nie ma jednak zastosowania w przypadku przedawnienia w sprawach karnych ${ }^{24}$. Innymi słowy, po upływie określonego w kan. 1362 czasu, sprawca przestępstwa nie może być już, z zasady, pociągnięty do odpowiedzialności karnej ${ }^{25}$.

Zgodnie z kan. 201: „\$1. Tempus continuum intellegitur quod nullam patitur interruptionem. $\$ 2$. Tempus utile intellegitur quod ita ius suum exercenti aut persequenti competit, ut ignoranti aut agere non valenti noncurrat”. Jak wynika z zacytowanego kanonu, czas ciągły (tempus continuum) to taki, który dla zaistnienia zależnych od niego skutków prawnych musi płynąć w sposób nieprzerwany. Innymi

\footnotetext{
${ }^{22}$ Ma tutaj miejsce tzw. kanonizacja ustaw cywilnych w myśl kan. 22. Zob. V. De Paolis - A. D'Auria, Le Norme Generali. Commento al Codice di Diritto Canonico. Libro Primo, Roma 2008, s. 495.

${ }^{23}$ Tamże, s. 495-496.

${ }^{24}$ Brak wymogu dobrej wiary w przypadku przedawnienia actio criminalis i poenalis, jest wyrazem korzystniejszego nastawienia ustawodawcy na rzecz sprawcy. Mamy tutaj do czynienia z praktycznym zastosowaniem zasady favor rei, jaka wyraźnie została wyartykułowana w Kodeksie kanonów Kościołów wschodnich w kan. $1404 \$ 1$ : „In poenis benignior est interpretatio facienda”. Por. L. LLOBELL, Sull'interruzione e sulla sospensione..., s. 650.

${ }^{25}$ Pewnym wyjątkiem od tej zasady są przestępstwa zastrzeżone dla Kongregacji Nauki Wiary o czym będzie mowa w dalszej części artykułu.
} 
słowy, jest to czas niepodzielny. Ponieważ czas ze swej natury biegnie w sposób ciągły, nieprzerwany, przyjmuje się, że czas przyznany przez prawo również jest ciągły ${ }^{26}$. Czas użyteczny (tempus utile) to z kolei czas przysługujący wykonującemu lub dochodzącemu swego prawa, a charakteryzujący się tym, że nie płynie dla niewiedzącego lub niemogącego działać - czas ten zatem może mieć przerwy. Czas użyteczny zachodzi wtedy, gdy w prawie zostało to przewidziane wprost (kan. 152, kan. 165, kan. $182 \$ 1$, kan. $1460 \$ 3$, kan. $1592 \$ 2$, kan. 1668 $\$ 2$, kan. $1734 \$ 2$, kan. $1744 \$ 1$ ); pośrednio (kan. 379, kan. $382 \$ 2$, kan. $527 \S 3$, kan. 1520); gdy prawo wprawdzie nie postanawia tego ani wprost ani pośrednio, ale termin przyznaje się jakiejś osobie bez szkody dla innych osób czy ogółu (kan. 700, kan. 1357 \$2, kan. 1735, kan. $1742 \$ 1$ ). Przy terminach procesowych (kan. 1465-1467) przyjmuje się, że czas przeznaczony stronom to czas użyteczny, natomiast sądowi to czas ciągły ${ }^{27}$.

Przy obliczaniu przedawnienia należy mieć na uwadze dwa kluczowe terminy: początkowy i końcowy. Zgodnie z kan. 203: „\$1. Dies a quo non computatur in termino, nisi huius initium coincidat cum inito diei aut aliud expresse in iure caveatur. $\$ 2$. Nisi contrarium statuatur, dies ad quem computatur in termino, qui, si tempus constet uno vel pluribus mensibus aut annis, una vel pluribus hebdomadis, finitur expleto ultimo die eiusdem numeri aut, si mensis die eiusdem numeri careat, expleto ultimo die mensie". Tak więc z zasady pierwszego dnia (dies a quo) nie wlicza się do terminu. Wyjątkowo jednak należy ten dzień brać pod uwagę, jeżeli początek zbiega się z początkiem dnia, albo prawo wyraźnie zastrzega coś innego. Natomiast termin końcowy (dies ad quem) to ostatni dzień, który jest wliczany do terminu ${ }^{28}$.

Dies a quo w przypadku przestępstw to dzień popełnienia przestępstwa, czyli dzień, w którym nastąpiły te działania lub zaniechania,

\footnotetext{
${ }^{26}$ J. KRukowski - R. SobAński, Komentarz do Kodeksu prawa kanonicznego. Tom I, Księga I Normy Ogólne, Poznań 2003, s. 293.

${ }_{27}$ Tamże, s. 293-294.

${ }^{28}$ Tamże, s. 295-296.
} 
które istotnie decydują o zaistnieniu danego przestępstwa. Innymi słowy, terminem początkowym przedawnienia $\mathrm{w}$ przypadku przestępstw będzie ten dzień, w którym zostały zrealizowane wszystkie znamiona czynu zabronionego pod groźbą sankcji karnej. Natomiast terminem końcowym (dies ad quem) będzie ostatni dzień licząc od terminu początkowego. Zgodnie $\mathrm{z}$ tym, co zostało powiedziane powyżej, dnia, w którym dokonano przestępstwa, nie wlicza się do okresu przedawnienia, gdy dokonanie nie zbiega się z początkiem dnia. Przedawnienie nastąpi dopiero po upływie ostatniego dnia. Przy obliczaniu terminów przedawnienia należy mieć na uwadze to, że w prawie kanonicznym możemy spotkać się z różnymi rodzajami przestępstw: materialnymi, formalnymi, permanentnymi, habitualnymi. W przypadku przestępstw materialnych ${ }^{29}$ przedawnienie liczy się od dnia zaistnienia skutku, w przypadku przestępstw formalnych $^{30}$ - od dnia, w którym nastąpiło działanie lub zaniechanie działania zabronionego prawem, $\mathrm{w}$ przypadku przestępstw permanentnych ${ }^{31}$

\footnotetext{
${ }^{29} \mathrm{~W}$ tego rodzaju przestępstwach, przestępstwo nie będzie mogło zostać uznane za dokonane (delictum consummatum) jeśli nie zaistnieje określony skutek działania przestępnego. Przykładowo w przypadku przestępstwa zabójstwa musi nastąpić śmierć człowieka (kan. 1397) a w przypadku przestępstwa aborcji musi nastąpić śmierć dziecka poczętego ale jeszcze nienarodzonego (kan. 1398).

${ }^{30} \mathrm{~W}$ przypadku tego rodzaju przestępstw, przestępstwo będzie uznane za dokonane (delilctum consummatum) jeśli będzie miało miejsce samo przestępcze działanie lub zaniechanie, niezależnie od tego czy zamierzony przez działającego skutek zaistnieje. Przykładowo w przypadku przestępstwa solicytacji (kan. 1387), wystarczy samo nakłanianie do grzechu przeciwko szóstemu przykazaniu Dekalogu niezależnie od tego, czy faktycznie do takiego zamierzonego naruszenia dojdzie. Podobnie rzecz ma się w przypadku przestępstwa zaboru i/lub przechowywania postaci konsekrowanych w celach świętokradczych (kan. 1367). Także tutaj, przestępczy jest już sam fakt zaboru/przechowywania postaci konsekrowanych w celu świętokradczym niezależnie od tego, czy faktycznie dojdzie do wykonania takiej czynności profanacyjnej.

${ }^{31}$ Polegające na stworzeniu przez sprawcę trwałego stanu przestępnego zakazanego prawem karnym. Zachodzi zatem wtedy, kiedy zostaje utrzymywany skutek spowodowany czynem przestępnym. Jak w przypadku oddania dzieci na wychowanie w religii niekatolickiej (kan. 1366), herezji lub apostazji od wiary (kan. 1364), pozbawienia wolności (kan. 1397), konkubinatu (kan. $1395 \$ 1)$.
} 
i habitualnych ${ }^{32}$ - od dnia ich ustania ${ }^{33}$. Natomiast w przypadku usiłowania popełnienia przestępstwa przedawnienie biegnie od dnia, w którym sprawca dokonał ostatniej czynności będącej częścią składową tego usiłowania ${ }^{34}$.

Przyjmuje się, że racją uzasadniającą instytucję przedawnienia jest zapewnienie porządku oraz pewności prawnej w zakresie praw subiektywnych. Chodzi zatem m.in. o zapobieganie sporom w sprawach trudnych do udowodnienia, ze względu na to, że wraz z upływem czasu coraz trudniejsze staje się uzyskiwanie dowodów ${ }^{35}$. Podobne uzasadnienia będą się odnosiły do instytucji przedawnienia w przypadku przestępstw kanonicznych. Niemniej jednak w doktrynie kanonistycznej wskazuje się na kilka różnych racji przedawnienia: przyczyny natury procesowej, poprawę przestępcy oraz przedawnienie jako swego rodzaju karę ${ }^{36}$. Uzasadnienie natury procesowej wynika z tego, iż po upływie określonego czasu mogą pojawić się przeszkody w zebraniu materiału dowodowego (zatarcie w pamięci wydarzeń i faktów). Z kolei przyczyny natury materialnej wynikają $\mathrm{z}$ tego, że po pewnym czasie ulega zmianie reakcja społeczna wywołana przestępstwem (zapomnienie i pobłażliwość). Racją przemawiającą za przedawnieniem może być także fakt poprawy przestępcy. Jeśli ktoś przez szereg lat umiał powstrzymać się od popełnienia przestępstwa, to można przypuszczać, że szczerze się poprawił (favor rei). Przedawnienie może być też postrzegane jako swego rodzaju

\footnotetext{
${ }^{32}$ Przestępstwo habitualne polega na wielokrotnym przekraczaniu tego samego prawa, z których każde naruszenie stanowi odrębne przestępstwo, ale ze względu na zły zamiar sprawcy traktowane są jako jedna całość. Dotyczy zatem pewnej jednolitej działalności przestępcy. Innymi słowy jeśli składa się z szeregu działań przestępnych, które ze względu na jedną decyzję woli stanowią jeden czyn w znaczeniu prawnym. Jak w przypadku uprawiania handlu przez duchownych lub zakonników (kan. 1392), czy systematycznego okradania przez skarbnika/ekonoma powierzonej mu kasy (kan. 1377).

${ }^{33}$ KPK/1983, kan. $1362 \$ 2$.

${ }^{34}$ Por. J. SyryjCzy K, dz. cyt., s. 323-324.

${ }^{35}$ J. Krukowski - R. Sobański, dz. cyt., s. 286. Zob. także V. De Paolis A. D’Auria, Le Norme Generali..., s. 493-494.

${ }^{36}$ M. МүrсHA, dz. cyt., s. 767-770.
} 
kara. Ciągły niepokój i obawa przed zdemaskowaniem mogą być dla sprawcy przyczyną bardzo przykrych doznań. Należy zauważyć, że różnorodność przyczyn uzasadniających instytucję przedawnienia wskazuje na istnienie pewnej polaryzacji pomiędzy favor rei $\mathrm{i}$ bonum commune Ecclesiae. Nie ulega jednakże wątpliwości, że ostateczną racją przyjęcia instytucji przedawnienia jest współcześnie czas $^{37}$.

\section{Przedawnienie w ramach odpowiedzialności karnej}

\subsection{Wymierzanie i wykonanie kary}

Jak już zostało powiedziane wcześniej, Kodeks prawa kanonicznego z 1983 roku przewiduje trzy rodzaje skarg wiążących się ściśle z popełnionym przestępstwem: skargę kryminalną (actio criminalis ${ }^{38}$ ), skargę

\footnotetext{
${ }^{37}$ Por. J. Syry JCZy K, dz. cyt., s. 320-321; M. MyrCha, dz. cyt., s. 767-770. Por. także S. Paglialunga, dz. cyt., s. 332; 339-342; D.G. Astigueta, dz. cyt., s. 120-122.

${ }^{38} \mathrm{KPK} / 1983$, kan. 1362; 1720; 1726. W przywołanych kanonach użyto sformułowania actio criminalis, co na język polski zostało przetłumaczone jako skarga karna, a w kan. 1726 jako skarga kryminalna. Wydaje się, że to ostatnie sformułowanie lepiej oddaje znaczenie łacińskiego terminu actio criminalis. Por. J. SYRYJCZYK, dz. cyt., s. 319. Można sobie jednak zadać pytanie, czy użyte w KPK/1983 sformułowanie actio criminalis oddaje istotę działania, do którego się odnosi. Przymiotnik criminalis pochodzi od rzeczownika crimen. Jak wiadomo termin ten, zarówno w KPK/1917 jak w KPK/1983 jest używany, i to zamiennie z terminem delictum, na określenie przestępstwa (Por. D. BoreK, Concursus in delicto. Formy zjawiskowe przestępstwa w kanonicznym prawie karnym (studium prawno-historyczne), Warszawa 2014, s. 45-48). A zatem tak naprawdę należałoby tutaj mówić nie o skardze kryminalnej, ale o skardze przestępczej. Z drugiej jednak strony warto zauważyć, że w Kodeksie kanonów Kościołów wschodnich termin criminalis został zamieniony na poenalis. Zob. Pontificium Consilium de Legum Textibus Interpretandis, Acta et documenta PCCICR, Conregatio Plenaria diebus 20-29 octobris 1981 habita, Typis Polyglotiis Vaticanis 1991, s. 565-574. Może zatem byłoby lepiej także i w przypadku KPK użyć sformułowania skarga penalna (actio poenalis), ponieważ jej celem jest właśnie ewentualne pociągnięcie sprawcy do odpowiedzialności karnej, a nie przestępstwo (crimen/delictum) samo w sobie. W takim jednakże przypadku w odniesieniu do dotychczasowej actio poenalis należałoby używać sformułowania actio ad poenam exequendam, zgodnie z tym, co się przewiduje w kan. 1362 \$ 1 KPK/1983.
} 
o wykonanie kary (actio ad poenam exsequendam ${ }^{39}$ ) zwaną inaczej skargą penalną lub karną ${ }^{40}$ oraz skargę o naprawienie szkód powstałych z popełnionego przestępstwa (actio ad damna reparanda ${ }^{41}$ ).

Skarga kryminalna to działanie publiczne wynikające $\mathrm{z}$ prawa, którego celem jest wymierzenie lub deklarowanie kary. W przypadku skargi penalnej mamy natomiast do czynienia z prawem do zagwarantowania przestrzegania lub wykonania kary, która została już wymierzona/deklarowana wyrokiem bądź dekretem pozasądowym. Skarga penalna wiąże się ściśle ze skargą kryminalną, ale jednocześnie jest niezależna od niej, albowiem ze swojej strony jest skierowana na wykonanie kary wymierzonej lub deklarowanej ${ }^{42}$. Ostatnia ze wspomnianych skarg to wprawdzie skarga sporna, ale może być wniesiona w ramach prowadzonego procesu karnego przez stronę poszkodowaną ${ }^{43}$. Zatem fakt popełnienia przestępstwa może skutkować rożnego rodzaju skargami: skargą zmierzającą do pociągnięcia sprawcy przestępstwa do odpowiedzialności karnej, skargą o wykonanie kary już wymierzonej/deklarowanej i skargą o naprawie szkód powstałych z przestępstwa. Należy zaznaczyć, że w obowiązującym kanonicznym prawie karnym mamy do czynienia z przedawnieniem jedynie w odniesieniu do dwóch pierwszych rodzajów skarg, a mianowicie skargi kryminalnej (actio criminalis) oraz skargi penalnej (actio poenalis) $^{44}$. Jeżeli chodzi natomiast o ewentualne przedawnienie

\footnotetext{
${ }^{39}$ KPK/1983, kan. 1363.

${ }^{40}$ Por. J. SyryjCzy K, dz. cyt., s. 326.

${ }^{41}$ KPK/1983, kan. $1729 \$ 1$.

${ }^{42}$ Por. J. SyryjCzy K, dz. cyt., s. 319-321.

${ }^{43}$ Kodeks prawa kanonicznego z 1983 roku, podobnie jak i ten z 1917 roku, przewiduje niezależność skargi kryminalnej od skargi o naprawienie szkód zgodnie z kan. 128 i 1729. Te dwie skargi, chociaż posiadają wspólne korzenie, jednak ze względu na różnorodną naturę, są niezależne. Por. D. Ciтo, La prescrizione in materia penale..., s. 227.

${ }^{44}$ Aktualne przepisy z KPK/1983 w materii przedawnienia skargi kryminalnej oraz penalnej zasadniczo zbieżne są z analogicznymi dyspozycjami z Kodeksu z 1917 roku. Zob. KPK/1917, kan. 2240; 1701-1705. Zob. także, D.G. AstiguetA, dz. cyt., s. 114-120.
} 
skargi o naprawienie szkód, zagadnienie to zostanie omówione w dalszej części artykułu.

Kodeks prawa kanonicznego z 1983 roku przewiduje czas $^{45}$, różny w zależności od rodzaju popełnionego przestępstwa, po upływie którego następuje wygaśnięcie skargi kryminalnej ${ }^{46}$. Mamy tutaj zatem do czynienia $\mathrm{z}$ wygaśnięciem przysługującego promotorowi sprawiedliwości ${ }^{47}$ (jeśli ordynariusz zdecydował o wszczęciu procesu in via iudicialis) albo ordynariuszowi (jeśli zdecydował on, że proces będzie się toczył in via administrativa $)^{48}$ ius accusandi, przez co ewentualne wszczęcie i/lub prowadzenie postępowania jest niemożliwe.

${ }^{45} \mathrm{~W}$ przypadku przedawnienia możliwości ścigania sprawcy przestępstwa należy pamiętać o tym, że czas przedawnienia to czas ciągły. W dobie obowiązywania KPK/1917 istniały pewne wątpliwości odnośnie do tego, czy czas przedawnienia to czas ciągły, czy też może użyteczny. Takie wątpliwości były spowodowane pewną sprzecznością, jaka zachodziła pomiędzy kan. $1705 \$ 1$ i kan. 1702. Z pierwszego z przywołanych kanonów wynikałoby, że czas przedawnienia to czas ciągły: „Praescriptio (...) currit (...) in criminalibus, a die patrati delicti”. Z kolei według drugiego ze wspomnianych kanonów, czas przedawnienia miałby być użyteczny: „Omnis criminalis actio perimitur (...) lapsu temporis utilis ad actionem criminalem proponendam”. Zdania ówczesnej doktryny były podzielone odnośnie do tego, któremu z zacytowanych kanonów należy przyznać słuszność, gdyż ewidentnie istniała pomiędzy nimi sprzeczność. Por. M. MYrcha, dz. cyt., s. 803-808.

${ }^{46}$ Należy w tym miejscu zaznaczyć, że w odniesieniu do terminów przedawnienia skargi kryminalnej i penalnej, nie mogą być zastosowane odnośne przepisy państwowe w myśl kan. 197. Kwestia ta bowiem jest w całości regulowana przez prawo kanoniczne. Por. L. Llobell, Sull'interruzione e sulla sospensione..., s. 649.

${ }^{47}$ Oskarżycielem w procesie karnym na drodze sądowej jest rzecznik sprawiedliwości (kan. 1721). Jednakże to ordynariusz jest dominus całej procedury karnej. Biorąc pod uwagę dyspozycję jaką znajdujemy w kan. $1718 \$ 1$ n. 1, ordynariusz stwierdziwszy, że nastąpiło już przedawnienie skargi kryminalnej nie może wszcząć procesu karnego i powinien zarządzić archiwizację postępowania (por. KPK/1983, kan. 1719). Mówimy tutaj o niedopuszczalności postępowania karnego - por. kan. $1718 \$ 1$, n. 1; 1720, n. 3. Niemniej jednak może się zdarzyć, że w momencie podejmowania przez ordynariusza decyzji przewidzianych w kan. 1341, 1342 i 1718, bieg przedawnienia będzie jeszcze w toku, który zakończy się dopiero w momencie redagowania skargi oskarżającej przez rzecznika sprawiedliwości.

${ }^{48}$ Oskarżycielem w procesie karnym na drodze administracyjnej jest ordynariusz. Wydaje się jednak, że nic nie stoi na przeszkodzie, aby zadanie to zostało 
Czas przedawnienia biegnie zgodnie z kan. 1362: „\$1. Actio criminalis praescriptione extinguitur triennio, nisi agatur: $1^{\circ}$ de delictis Congregationi pro Doctrina Fidei reservatis; $2^{\circ}$ de actione ob delicta de quibus in cann. 1394, 1395, 1397, 1398, quae quinquennio praescribitur; $3^{\circ}$ de delictis quae non sunt iure communi punita, si lex particularis alium praescriptionis terminum statuerit. $\$ 2$. Praescriptio decurrit ex die quo delictum patratum est, vel, si delictum sit permanens vel habituale, ex die quo cessavit".

Prawo kanoniczne przewiduje czasokresy na przedawnienie się prawa ścigania (actio criminalis) w myśl kan. 1362. Po pierwsze są to trzy lata jako zasada ogólna odnosząca się do wszystkich przestępstw kanonicznych, zasadniczo bowiem prawo kanoniczne nie przewiduje przestępstw, z tytułu których możliwość ścigania nie ulegałaby przedawnieniu ${ }^{49}$. Wyjątek od tej zasady stanowią przestępstwa, w przypadku których actio criminalis przedawnia się po upływie pięciu lat. Należą do nich: usiłowanie zawarcia małżeństwa przez duchownego i zakonnika po złożeniu ślubów wieczystych (kan. 1394); dopuszczenie się przez duchownego przestępstwa konkubinatu oraz inne naruszenia przeciwko szóstemu przykazaniu Dekalogu (kan. 1395); zabójstwo, porwanie, zranienie, okaleczenie (kan. 1397); aborcja (kan. 1398). Wyjątek od zasady trzech lat odnosi się także do przestępstw zastrzeżonych dla Kongregacji Nauki Wiary, w przypadku których actio criminalis przedawnia się aktualnie po

powierzone rzecznikowi sprawiedliwości. Biorąc jednak pod uwagę ekonomię, jaką ustawodawca kieruje się przewidując wymierzanie/deklarowanie kary na drodze administracyjnej, należałoby przyjąć, że rolę oskarżyciela w procesie karnym na drodze administracyjnej może pełnić ten, kto taki proces prowadzi: a więc sam ordynariusz lub też osoba przez niego do tego zadania delegowana (kan. 1720).

${ }^{49}$ Wprawdzie D.G. Astigueta w jednym ze swoich artykułów zadaje sobie pytanie dotyczące problematyki nieprzedawnialności przestępstw w Kościele, ale jest to raczej pytanie retoryczne. Świadczy o tym to, że także w przypadku przestępstw zastrzeżonych dla Kongregacji Nauki Wiary z zasady przewiduje się przedawnienie możliwości ścigania, a uprawienie do uchylenia tegoż przepisu należy traktować jak wyjątek od zasady. Por. Normy de delictis reservatis z 2010 r., art. 7; D.G. Astigueta, dz. cyt., s. 103-158. 
upływie dwudziestu lat ${ }^{50}$. Chodzi tutaj o dosyć obszerny katalog, który obejmuje przestępstwa przeciwko: wierze (herezja, apostazja i schizma); Eucharystii (zabieranie lub przechowywanie w celu świętokradczym, profanacja postaci konsekrowanych, usiłowanie czynności liturgicznej Ofiary eucharystycznej, symulowanie czynności liturgicznej Ofiary eucharystycznej, koncelebrowanie Ofiary eucharystycznej z szafarzami wspólnot kościelnych, które nie posiadają sukcesji apostolskiej oraz nie uznają sakramentalności święceń kapłańskich, konsekracja - in sacrilegum finem - jednej postaci lub obydwu w czasie eucharystycznej celebracji lub też poza nią); pokucie (rozgrzeszenie wspólnika w grzechu przeciwko szóstemu przykazaniu Dekalogu, usiłowanie rozgrzeszenia sakramentalnego lub zakazane słuchanie spowiedzi, symulowanie rozgrzeszenia sakramentalnego, nakłanianie penitenta do grzechu przeciwko szóstemu przykazaniu Dekalogu w akcie spowiedzi albo z okazji spowiedzi lub pod jej pretekstem, jeżeli ma na celu grzech z samym spowiednikiem, bezpośrednia i pośrednia zdrada tajemnicy sakramentalnej, nagrywanie przy pomocy jakiegokolwiek instrumentu technicznego lub dokonane ze złośliwością rozpowszechnianie za pomocą środków społecznego przekazu tego, co jest mówione przez spowiednika lub penitenta podczas spowiedzi sakramentalnej, prawdziwej lub fałszywej); święceniom (usiłowanie udzielenia/przyjęcia święceń przez kobietę); obyczajom (przestępstwa przeciwko szóstemu przykazaniu Dekalogu popełnione przez duchownego z osobą małoletnią poniżej 18 roku życia (z małoletnim zrównana jest osoba, która habitualnie posiada niepełne używanie rozumu), nabywanie, przechowywanie lub rozpowszechnianie w celach lubieżnych obrazów pornograficznych z małoletnimi poniżej czternastu lat, dokonane przez duchownego w jakikolwiek sposób i przy użyciu jakiegokolwiek narzędzia ${ }^{51}$. Ponadto, zgodnie kan. $1362 \S 1, \mathrm{n} .3$, może być przewidziany inny czas w odniesieniu do przestępstw, które nie są karane na podstawie prawa

\footnotetext{
${ }^{50}$ Normy de delictis reservatis z 2010 r., art. 7.

${ }^{51}$ Por. Normy de delictis reservatis z 2010 r., art. 2-6 i 7.
} 
powszechnego. Ustawa partykularna może zatem przewidywać inny upływ czasu potrzebny do przedawnienia skargi kryminalnej.

Wygaśnięcie skargi kryminalnej sprawia, że niemożliwe jest nie tylko wprowadzenie skargi oskarżającej, ale także kontynuowanie postępowania $^{52}$. Zasada ta została wyrażona także w dekrecie definitywnym trybunału Roty Rzymskiej z 1993 roku $^{53}$. W dokumencie tym zostały wyrażone te same zasady dotyczące przedawnienia skargi kryminalnej w związku ze sprawą, w której trybunał pierwszej instancji, nie biorąc pod uwagę przedawnienia skargi kryminalnej, doszedł aż do wydania sentencji: „2. iuxta can. 1362, praescriptionem absolute extinxisse actionem criminalem ob expiratu a die quo patrata fuerunt delicta utile temporis spatium ad illa persequenda sicut in eiusdem canonis $₫ 2$ statutum. 3. ob praescriptam eandem criminalem actionem, totum celebratum procesum ipso iure corruisse" ${ }^{24}$. Tak więc wraz z nastąpieniem przedawnienia skargi kryminalnej ustają, na mocy samego prawa, także działania procesowe ${ }^{55}$.

Przedawnienie skargi penalnej (actio ad poenam exsequendam), uzależnione od przedawnienia skargi kryminalnej, posiada przynajmniej częściowy udział w jej uzasadnieniach wynikających z dobra publicznego. Przedawnienie skargi penalnej napotykało na mocne głosy krytyczne, także na płaszczyźnie prawa państwowego, ze względu na fakt istnienia już sentencji definitywnej ${ }^{56}$. Niemniej jednak należy zauważyć, że po upływie dłuższego czasu zanika racja karania ze względu na istniejącą trudność w realizacji i osiągnięciu celów kary,

\footnotetext{
${ }^{52}$ Zgodnie $\mathrm{z}$ tym, co zanotował M. LEGA: „quare proinde quando iam extat praescriptio opponi debet ex officio ex can. 1619 non ad perimendam actionem sed ad impediendam instantiae introductionem aut procesuctionem", M. LEGA - V. BARtoccetti, Commentarius in iudicia ecclesiastica iuxta Codicem iuris canonici, IV Roma 1889-1905, s. 499.

53 Tribunale Apostolico della Rota Romana, Decreto c. Ragni, 16 febbraio 1993, Ius Ecclesiae 6 (1994), s. 217-229.

54 Tribunale Apostolico della Rota Romana, Decreto c. Ragni, 16 febbraio 1993, Ius Ecclesiae 6 (1994), s. 217-229.

${ }^{55}$ Por. D. Cito, La prescrizione in materia penale..., s. 225.

${ }^{56}$ Por. Tamże, s. 227.
} 
o których mowa w kan. 1341, czyli uzyskania: naprawy zgorszenia, przywrócenia naruszonej sprawiedliwości oraz poprawy winnego. W odniesieniu do przedawnienia skargi penalnej, w kan. 1363 przewiduje się następującą dyspozycję: „ $\$ 1$. Si intra terminos de quibus in can. 1362, ex die quo sententia condemnatoria in rem iudicatam transierit computandos, non sit reo notificatum exsecutorium iudicis decretum de quo in can. 1651, actio ad poenam exsequendam praescriptione extinguitur. $\$ 2$. Idem valet, servatis servandis, si poena per decretum extra iudicium irrogata sit”. Zgodnie zatem z kan. 1363, wygaśnięcie skargi penalnej może mieć miejsce dopiero po wyroku lub dekrecie skazującym. W grę wchodzą jedynie takie dekrety i wyroki, które są prawomocne, gdyż dekret i wyrok które nie są jeszcze prawomocne mogą zawsze ulec zmianie. Terminem a quo, czyli punktem wyjścia jest więc prawomocny wyrok bądź dekret, który jest skazujący ${ }^{57}$. Obowiązuje ten sam czas, co w przypadku przedawnienia skargi kryminalnej, z tą różnicą, że przedawnienie skargi penalnej liczymy od dnia wydania dekretu wykonawczego (kan. 1651).

W przypadku wyroku skazującego, wniesienie restitutio in integrum (i analogicznego beneficium novae audientiae w procesie administracyjnym) będzie możliwe, jeśli kara jest wykonywana, albo jeśli skarga ad poenam exsequendam jeszcze się nie przedawniła w myśl kan. 1363. Przedawnienie skargi ad poenam exsequendam dotyczy

\footnotetext{
${ }^{57}$ Ustawodawca w kan. $1363 \$ 1$-2 mówi o wyroku i dekrecie skazującym, który przeszedł w stan rzeczy osądzonej. Tym samym, nie będzie mowy o actio ad poenam exsequendam, w przypadku wyroku/dekretu uwalniającego, który to wyrok także przechodzi w stan rzeczy osądzonej. Taki wyrok/dekret uwalniający może być oczywiście zaskarżony przez tego, komu przysługuje actio poenalis (kan. 1721, 1724, $1727 \$ 2$ ), z powodu przyczyn, które pozwalają na wniesienie restitutio in integrum. Oczywiście pod warunkiem, że skarga kryminalna nie wygasła ze względu na terminy, o których mowa w kan. $1362 \$ 2$. Wydaje się bowiem, że w Kodeksie prawa kanonicznego z 1983 roku w ogóle nie przewiduje się przerwy biegu przedawnienia, a przynajmniej istnieją co do tego uzasadnione wątpliwości. Zagadnienie przerwy biegu przedawnienia wymaga jednak odrębnego, pogłębionego studium. Zob. J. Llobell, Sull'interruzione e sulla sospensione..., s. 658. Zob. także, M. MrrCHA, dz. cyt., s. 765.
} 
tylko tych przestępstw, za które oskarżony został ukarany, a wyrok/ dekret przeszedł w stan rzeczy osądzonej lato sensu $u^{58}\left(\right.$ kan. 1650) ${ }^{59}$.

\subsection{Deklarowanie kary}

Szczególnego znaczenia, w kontekście ewentualnego przedawnienia actio criminalis i actio poenalis, nabiera problematyka związana $\mathrm{z}$ przedawnieniem $\mathrm{w}$ przypadku kar latae sententiae. Przedawnienie skargi kryminalnej oraz penalnej w przypadku przestępstw, za które jest przewidziana kara latae sententiae, wiąże się z samą naturą tychże kar oraz z działaniem zmierzającym do ich deklaracji ${ }^{60}$. Kary latae sententiae to te, które wiążą na mocy samego prawa, tzn. bez interwencji sędziego lub przełożonego, a więc przez samo popełnienie przestępstwa z pełną odpowiedzialnością, jeśli prawo lub nakaz postanawiają to wyraźnie ${ }^{61}$. Kary latae sententiae, to - w aktualnym systemie karnym kanonicznym - z zasady kary poprawcze, czy inaczej cenzury. Oczywiście zgodnie z kan. $1336 \$ 2$, także i kary ekspiacyjne mogą wiązać na mocy samego prawa, ale tylko wtedy, kiedy polegają na zakazie wykonywania: władzy jurysdykcji, urzędu, zadania, prawa,

\footnotetext{
${ }^{58}$ Będzie tutaj chodziło zarówno o stan rzeczy osądzonej materialnie jak i formalnie. W pierwszym przypadku w grę wchodzą decyzje (wyrok/dekret) o charakterze konstytutywnym, podlegające zaskarżeniu poprzez restitutio in integrum. W drugim przypadku natomiast w grę wchodzą decyzje dotyczące stanu osób, a więc o naturze deklaratywnej, które mogą być zaskarżane poprzez nova causae propositio. Por. J. Llobell, Sull'interruzione e sulla sospensione..., s. 650, przypis n. 35 .

${ }^{59}$ Zatem nie będzie tutaj chodziło o nowe przestępstwa popełnione przez skazanego, ani o przestępstwa permanentne, dopóki działanie przestępcze nie zostanie zaprzestane. Ponadto o nowym przestępstwie będzie można mówić ewentualnie w przypadku niewywiązania się z obowiązków nałożonych karą (kan. 1393). J. LLoBELL, Sull'interruzione e sulla sospensione..., s. 659.

${ }^{60}$ Ten rodzaj kar jest przewidziany w ogólności za przestępstwa tajne lub za te poszczególne przestępstwa umyślne, które mogą wywołać zgorszenie i nie mogą być skutecznie ukarane przez kary ferendae sententiae (kan.1314). Kary latae sententiae stanowią zatem wyjątek od ogólnej zasady, dlatego też powinny być ustanawiane w szczególnych i wyjątkowych sytuacjach (kan. 1318).

${ }^{61}$ KPK/1983, kan. 1314.
} 
przywileju, uprawnienia, łaski, tytułu, odznaczenia, nawet czysto honorowego.

Omawiane obecnie zagadnienie, wbrew pozorom, może być jak najbardziej aktualne, a to m.in. z tego względu, że w aktualnym prawie kanoniczym dosyć często spotykamy się z karami poprawczymi zaciąganymi na mocy samego prawa. W przypadku kary ekskomuniki są to następujące niżej wyliczone przestępstwa. Ekskomunika latae sententiae, zarezerwowana dla Stolicy Apostolskiej, jest przewidziana w przypadku: profanacji postaci konsekrowanych (kan. 1367); przymusu fizycznego wobec Biskupa Rzymu (kan. $1370 \$ 1$ ); rozgrzeszenia wspólnika w grzechu przeciwko VI przykazaniu Dekalogu (kan. $1378 \$ 1$ ); konsekracji biskupa bez mandatu St. Ap. (kan. 1382); bezpośredniego naruszenia tajemnicy spowiedzi (kan. 1388 $\$ 1$ ); usiłowania udzielenia/przyjęcia święceń w przypadku kobiety ${ }^{62}$. Ekskomuniki latae sententiae niezarezerwowane dla Stolicy Apostolskiej, przewidziane są za następujące przestępstwa: apostazji, herezji i schizmy (kan. 1364); aborcji (kan. 1398); nagrywania i rozpowszechniania spowied $\mathrm{zi}^{63}$. Z kolei interdykty latae sententiae przewidziane są w następujących przestępstwach: przymusu fizycznego wobec Biskupa (kan. 1370 \$ 2); usiłowania sprawowania liturgicznej czynności ofiary eucharystycznej (kan. $1378 \$ 2$, n. 1.); usiłowania udzielenia sakramentalnego rozgrzeszenia lub słuchania spowiedzi sakramentalnej (kan. $1378 \$ 2$ n. 2); fałszywego oskarżenia spowiednika o przestępstwo solicytacji (kan. 1390 \$1); zakonnika ślubów wieczystych usiłującego zawrzeć małżeństwo (kan. 1394 \$2). I w końcu suspensy latae sententiae przewiduje się $\mathrm{w}$ odniesieniu do następujących przestępstw: przymusu fizycznego wobec Biskupa (kan. $1370 \$ 2$ ); usiłowania sprawowania liturgicznej czynności ofiary eucharystycznej (kan. 1378

\footnotetext{
${ }^{62}$ Congregatio pro Doctrina Fidei, Decretum generale de delicto attentatae sacrae ordinationis mulieris, 19.12.2007, AAS 100 (2008), s. 403; Normy, de delictis reservatis z 2010 r., art. 5, n. 1 .

${ }^{63}$ Kara ekskomuniki latae sententiae była przewidziana za wspomniane przestępstwo do 2010 roku. Zob. Congregatio pro Doctrina Fidei, Decretum quo ad Paenitentiae sacramentum tuendum, 23.09.1988, AAS 80 (1988), s. 1367; Normy de delictis reservatis z 2010 r., art. $4 \$ 2$.
} 
$\$ 2$, n. 1); usiłowania udzielenia sakramentalnego rozgrzeszenia lub słuchania spowiedzi sakramentalnej (kan. $1378 \$ 2$, n. 2); przyjęcia święcenia bez zgodnych z prawem listów dymisoryjnych (kan. 1383); duchownego, który fałszywie oskarża spowiednika o przestępstwo solicytacji (kan. $1390 \$ 1$ ); duchownego usiłującego zawrzeć małżeństwo (kan. $1394 \$ 1$ ). Jak wynika z powyższego zestawienia, kary latae sententiae stanowią dosyć pokaźny zbiór kar dotyczących zarówno wiernych świeckich, duchownych, jak i osób konsekrowanych przez profesję rad ewangelicznych ${ }^{64}$. O aktualności problematyki związanej $\mathrm{z}$ ewentualnym przedawnieniem deklarowania kar latae sententiae przemawia i to, że spora część przestępstw należących do katalogu przestępstw zastrzeżonych dla Kongregacji Nauki Wiary jest obwarowana właśnie karami latae sententiae ${ }^{65}$.

Biorąc pod uwagę to, że kary latae sententiae zaciąga się poprzez sam fakt popełnienia przestępstwa ${ }^{66}$, można by domniemywać, że

${ }^{64}$ Mówiąc o zaciąganiu kar latae sententiae nie można zapominać o odpowiedzialności z tytułu współudziału w przestępstwie. Por. KPK/1983, kan. $1329 \$ 2$.

${ }^{65}$ Normy de delictis reservatis z 2010 r.: ekskomunika latae sententiae za apostazję, herezję i schizmę (art. 2; KPK/1983, kan. 1364); ekskomunika latae sententiae za profanację postaci konsekrowanych (art. $3 \$ 1$, n. 1; KPK/1983, kan. 1367); interdykt lub suspensa latae sententiae za usiłowanie sprawowania liturgicznej czynności Ofiary eucharystycznej (art. $3 \$ 1$, n. 2; KPK/1983, kan. $1378 \$ 2$, n. 1); ekskomunika latae sententiae za rozgrzeszenie wspólnika w grzechu przeciw szóstemu przykazaniu Dekalogu (art. $4 \$ 1$, n. 1; KPK/1983, kan. $1378 \$ 1$ ); ekskomunika latae sententiae za usiłowanie udzielenia rozgrzeszenia sakramentalnego albo słuchanie spowiedzi (art. $4 \$ 1$ n. 2; KPK/1983, kan. $1378 \$ 2$, n. 2); ekskomunika latae sententiae za bezpośrednią zdradę tajemnicy spowiedzi (art. $4 \$ 1$, n. 5; KPK/1983, kan. $1388 \S$ 1); ekskomunika latae sententiae za nagrywanie i rozpowszechnianie tego, co jest mówione w czasie spowiedzi (taka kara była przewidziana w dekrecie ogólnym z 1988 r. Zob. Congregatio pro Doctrina Fidei, Decretum quo ad Paenitentiae sacramentum tuendum, 23.09.1988, AAS 80 /1988/, s. 1367. Normy z 2010 roku przewidują w tym przypadku jedynie karę ferendae sententiae. Zob. art. $4 \$ 2$ ); ekskomunika latae sententiae za usiłowanie udzielenia święceń kobiecie (art. 5, n. 1).

${ }^{66} \mathrm{KPK} / 1983$, kan. 1314. Należy pamiętać, że warunkiem wymiaru kar poprawczych zarówno tych ferendae jak i latae sententiae jest popełnienie przestępstwa oraz upór. Stąd też konieczne jest wcześniejsze, przynajmniej jedno upomnienie 
nie może być tutaj mowy o przedawnieniu skargi kryminalnej, a to dlatego iż „skazanie” właściwie już nastąpiło, z woli ustawodawcy, $\mathrm{w}$ momencie popełnienia przestępstwa ${ }^{67}$. Podobnie nie może być mowy o przedawnieniu skargi penalnej ${ }^{68}$. W takim ujęciu skarga kryminalna posiadałaby jedynie charakter deklaratoryjny, a więc byłaby możliwa do przeprowadzenia kiedykolwiek. Jak zauważa jednakże P. Ciprotti: „questa figura (il processo penale declaratorio) si combina sempre con il processo di condanna costitutiva, giacche dalla pronuncia della sentenza o del precetto si producono nuove situazioni giuridiche che prima non esistevano" ${ }^{\text {. A }}$ zatem, w przypadku deklaracji faktu zaciągnięcia kary latae sententiae mamy do czynienia nie tylko $\mathrm{z}$ deklaracją tego, co już nastąpiło ipso iure ${ }^{70}$, ale także z elementem konstytutywnym, to znaczy spowodowaniem zmiany sytuacji, w której znajduje się skazany w wyniku deklarowania zaciągniętej kary, co pociąga za sobą dodatkowe skutki ${ }^{71}$. Zgodnie z powyższym można

kanoniczne (kan. 1347). Upomnienie kanoniczne w przypadku kar poprawczych jest regułą, koniecznością do ważnego ich wymierzenia, natomiast w przypadku kar ekspiacyjnych takie upomnienie jest raczej wyjątkiem (por. kan. $1395 \$ 1$ ). Do zaciągnięcia kar latae sententiae wystarczy upomnienie ustawowe. Innymi słowy sprawca naruszenia, za które przewidziany jest wspominany rodzaj kary musi wiedzieć o tym, że za dane naruszenie grozi mu zaciągnięcie kary latae sententiae. Oczywiście, w toku postępowania zmierzającego do zadeklarowania faktu zaciągnięcia kary latae sententiae, należy uwzględnić wszystkie okoliczności, które zgodnie z prawem mogą mieć tutaj znaczenie (por. KPK/1983, kan. 1323-1324).

${ }^{67}$ Davide Cito zauważył, że w przypadku kar latae sententiae, nie ma potrzeby wydawania dekretu wykonawczego, gdyż kara jest wykonywana od razu. D. Ciтo, La prescrizione in materia penale..., s. 227-228.

${ }^{68}$ Zgodnie z tym, co się postanawiało w KPK/1917, kan. $2232 \$ 1$ : „, Poena latae sententiae, sive medicinalis sive vindicativa, delinquentem, qui delicti sibi sit conscius, ipso facto in utroque foro tenet".

${ }^{69}$ P. Сiprotti, Diritto penale canonico, Enciclopedia giuridica Treccani, Istituto della Enciclopedia Italiana, t. 11, Roma 1989, s. 13.

${ }^{70}$ Zob. KPK/1983, kan. $1331 \S 1 ; 1332 ; 1333 \$ 1$.

${ }^{71}$ Zob. KPK/1983, kan. $1331 \S 2 ; 1332 ; 1333 \S 2$. 
przyjąć, że także w przypadku kar latae sententiae przedawnieniu ulega możliwość deklarowania faktu zaciągnięcia takiej kary ${ }^{72}$.

Kary latae sententiae są przewidziane w ogólności za przestępstwa tajne lub za te poszczególne przestępstwa umyślne, które mogą wywołać zgorszenie, ale nie mogą być skutecznie ukarane przez kary ferendae sententiae ${ }^{73}$. W związku z powyższym, można sobie zadać pytanie odnośnie tego, czy na instytucję przedawnienia w przypadku kar latae sententiae będzie miało wpływ to, czy przestępstwo jest tajne ${ }^{74}$, czy też notoryczne ${ }^{75}$. W świetle tego, co zostało powiedziane powyżej,

${ }^{72}$ Takiego zdania jest także J. Llobell oraz obecnie D. Cito. Zob. J. Llobell, Il giusto processo penale..., s. 649; D. Ciтo, La prescrizione in materia penale..., s. 228-231. KPK/1983, kan. 1362; Normy de delictis reservatis z 2010 r., art. 7.

${ }^{73}$ Por. KPK/1983, kan. 1318.

${ }^{74}$ Przestępstwo jest tajne (delictum occultum), jeśli nie jest publiczne, czyli nie jest rozgłoszone i nie ma obawy, że będzie rozgłoszone. Jeżeli przestępstwo jest znane kilku zaledwie osobom i to dyskretnym, to jest ono tajnym, jeżeli natomiast wie o nim jedna lub druga osoba gadatliwa, jest jawnym, publicznym. Przestępstwo może być tajne materialnie (delictum occultum materialiter), kiedy czyn przestępny jest nieznany i nie ma możliwości ujawnienia go. Ponadto przestępstwo może być tajne formalnie (delictum occultum formaliter), kiedy wprawdzie czyn przestępny jest znany, ale przypisywalność jest nieznana (np. ludzie wiedzą, że X zabił Y, ale mniemają, że zabił go we własnej obronie). KPK/1917, kan. 2197, n. 4. Por. F. BĄCzKowicz, Prawo Kanoniczne. Podręcznik dla duchowieństwa, tom 3, Opole 1958, s. 352.

${ }^{75} \mathrm{Z}$ przestępstwem notorycznym (delictum notorium) mamy do czynienia wtedy, kiedy jest ono tak oczywiste, iż w żaden sposób nie da się go ukryć ani usprawiedliwić, dzięki czemu nie wymaga udowodnienia. W tym wypadku w grę wchodzi stopień pewności prawnej co do działania przestępczego. Przestępstwo jest notoryczne notorycznością prawną (delictum notorium notorietate iuris), jeśli miał miejsce wyrok sądowy lub przyznanie się oskarżonego przed sądem. Natomiast przestępstwo będzie notoryczne notorycznością faktyczną (delictum notorium notorietate facti), jeśli jest publicznie znane i jest pewność co do poczytalności sprawcy. Pomiędzy przestępstwem notorycznym i publicznym istnieje zatem zasadnicza różnica. Otóż przy przestępstwie publicznym znany i rozgłoszony jest sam tylko fakt popełnienia przestępstwa, podczas gdy przy przestępstwie notorycznym pewną jest również poczytalność sprawcy. Przestępstwo notoryczne niekoniecznie jednak musi być publiczne; do notoryczności bowiem przestępstwa nie jest wymagane jego rozgłoszenie lub przewidywanie rozgłoszenia KPK/1917, kan. 2197, n. 1-3. Por. F. BĄCzKowicz, dz. cyt., s. 352-353. 
wydaje się, że z punktu widzenia upływu czasu koniecznego do przedawnienia (zarówno actio criminalis, jak i actio poenalis), nie będzie miało znaczenia to, czy jest to przestępstwo tajne, czy notoryczne. Prawo kanoniczne nie przewiduje bowiem instytucji zawieszenia ${ }^{76}$ biegu przedawnienia ze względu na charakter tajny przestępstwa, czy też jego notoryczność ${ }^{77}$. Innymi słowy, możliwość deklarowania faktu zaciągnięcia kary latae sententiae wygasa z zasady po upływie trzech lat, natomiast w odniesieniu do przestępstwa usiłowania zawarcia małżeństwa (kan. 1394) oraz przestępstwa aborcji (kan. 1398) po upływie pięciu lat ${ }^{78}$. Natomiast w przypadku przestępstw należących do kategorii delicta reservata będzie to okres dwudziestu lat, chyba że Kongregacja zdecyduje o uchyleniu okresu przedawnienia ${ }^{79}$. Można zatem przyjąć, że zasady dotyczące przedawnienia actio criminalis i poenalis dotyczą wszystkich przestępstw, gdyż KPK/1983 nie przewiduje przestępstw, które nie podlegają przedawnieniu.

\subsection{Przestępstwa zastrzeżone dla Kongregacji Nauki Wiary}

Zarówno w czasie obowiązywania KPK/1917 jak i w obecnej kodyfikacji łacińskiej i wschodniej, w doktrynie kanonistycznej autorzy podnosili nie tylko kwestię właściwej identyfikacji poszczególnych przestępstw należących do kategorii zastrzeżonych dla Kongregacji Nauki Wiary, ale także sprawę przedawnienia ścigania i karania za tę kategorię przestępstw ${ }^{80}$. Kwestie te były podnoszone, ponieważ

\footnotetext{
${ }^{76}$ Należy zaznaczyć, że w kanonicznym prawie karnym materialnym i formalnym nie spotykamy się w ogóle z instytucją zawieszenia biegu przedawnienia. Zagadnienie to, podobnie jak instytucja przerwy, wymaga odrębnego pogłębionego studium.

${ }^{77}$ Notoryczność faktu zaciągnięcia kary latae sententiae będzie miała ewentualnie znaczenie w kontekście zwolnienia z obowiązku zachowania kary, o czym mowa w kan. $1352 \$ 2$.

${ }^{78}$ KPK/1983, kan. 1362.

${ }^{79}$ Normy de delictis reservatis z 2010 r., art. 7.

80 "Sebbene l'art. 52 della costituzione apostolica Pastor Bonus preveda espressamente che tale Congregazione <giudica i delitti contro la fede e i delitti più gravi commessi sia contro la morale sia nella celebrazione dei sacramenti, che vengano ad essa segnalati e, all'occorrenza, procede a dichiarare o ad infliggere le sanzioni canoniche a norma del diritto, sia comune che proprio $>$, a tutt'oggi manca una
} 
wspominane Kodeksy odsyłały w tej materii do własnej dyscypliny Kongregacji. Autorzy zasadniczo zgadzali się w kwestii braku przedawnienia skargi w przypadku tychże przestępstw lub przynajmniej $\mathrm{w}$ przypadku niektórych $\mathrm{z}$ nich (przeciwko wierze oraz sollicitatio ad turpia $)^{81}$.

Wraz z promulgacją m.p. Sacramentorum Sanctitatis Tutela w 2001 roku, oraz wprowadzeniem późniejszych uzupełnieńn ${ }^{82}$ łącznie z tymi wprowadzonymi w 2010 roku $^{83}$, zostały usunięte wyżej wspomniane wątpliwości, ponieważ sprecyzowano obydwa zagadnienia. W odniesieniu do przedawnienia nowość polega na tym, że po raz pierwszy, także i w przypadku przestępstw zarezerwowanych dla Kongregacji Nauki Wiary, następowało przedawnienie zarówno w tym, co się odnosi do przedawnienia skargi kryminalnej jak i penalnej ${ }^{84}$. W odniesieniu do wszystkich przestępstw początkowo został ustalony okres dziesięciu lat, który zaczyna biec od czasu popełnienia przestępstwa, za wyjątkiem przestępstwa popełnionego przez duchownego z małoletnim poniżej osiemnastego roku życia. W tym ostatnim przypadku termin przedawnienia zaczyna biec od momentu, kiedy małoletni ukończy osiemnasty rok życia. W ten sposób zostało przejęte to,

chiara indicazione su quali siano questi delitti e quale sia il tempo di prescrizione", V. De Paolis - D. Cito, Le sanzioni nella Chiesa, Roma 2000 s. 274-275.

${ }^{81}$ D. Cito, La prescrizione in materia penale..., s. 221. Zob. także A. Borras, Les sanctions dans l'Eglise, Parigi 1990, s. 149; J. Llobell, I delitti riservati alla Congregazione per la Dottrina della Fede, Quaderni della Mandola 5, Milano 1997, s. 237-278.

${ }^{82}$ Congregatio Pro Doctrina FIDEI, Breve relazione circa le modifiche introdotte nelle Norme de gravioribus delictis riservato alla Conregazione per la Dottrina della Fede, 15 luglio 2010, AAS 102 (2010), s. 432-434. Por. także B.F. Pighin, dz. cyt., s. 616-618; Ius Ecclesiae 16 (2004), s. 313-321; J. LlobelL, Il giusto processo penale..., s. $169-171$.

${ }^{83}$ Normy de delictis reservatis z $2010 \mathrm{r}$.

${ }^{84}$ „Notandum est actionem criminalem de delictis Congragationi pro Doctrina Fidei reservatis praescriptione extingui decennio. Praescriptio decurrit ad normam iuris universalis et communis; in delicto autem cum minore a clerico patrato praescriptio decurrere incipit a die quo minor duodevicesimum aetatis annom explevit”, Normy de gravioribus delictis z $2001 \mathrm{r}$. 
co w tej kwestii przewidywały normy partykularne, jakie zostały przyjęte dla Stanów Zjednoczonych Ameryki Północnej w $1994^{85}$ i zatwierdzone do 2009 roku. Dyspozycja m.p. dotycząca przedawnienia zasadniczo była uznawana za wystarczającą ${ }^{86}$. Został bowiem przewidziany wystarczający czas w celu skutecznego ścigania za delicta graviora, które bardzo często posiadają charakter przestępstw habitualnych bądź permanentnych. Nie bez znaczenia pozostaje także i to, że na mocy m.p. Sacramemtorum Sanctitatis Tutela z 2001 roku liczba przestępstw podlegających kompetencji Kongregacji Nauki Wiary znacznie się powiększyła ${ }^{87}$. Gdyby przestępstwa te nie podlegały przedawnieniu, przepisy dotyczące przedawnienia byłyby zupełnie powierzchowne, ponieważ miałyby zastosowanie jedynie $\mathrm{w}$ odniesieniu do przestępstw o mniejszym znaczeniu ${ }^{88}$. Należy jednakże zauważyć, że w niedługim czasie po promulgacji Norm 2001 roku, bo już 7 listopada 2002 Ojciec Święty udzielił Kongregacji Nauki Wiary upoważnienia do uchylenia przedawnienia w poszczególnych przypadkach na uzasadniony wniosek ze strony zainteresowanego biskupa ${ }^{89}$.

${ }^{85}$ Segreteria di Stato, Rescript from Audience of His Holiness, Ius Ecclesiae 8 (1996), s. 193.

${ }^{86}$ „Un periodo sufficientemente lungo, e certamente molto più lungo di quanto previsto nella legislazione precedente. La lunghezza del periodo diventa ancora più rilevante, se si pensa che il tempo del decorso è stato fissato ai 18 anni della vittima del crimine. Si pensa infatti che il bambino non sia ancora in grado di far valere il diritto di avviare l'azione penale se non ha raggiunto un certo limite di anni, ossia se non è uscito dalla minore età", V. DE PAOLIs, Norme de gravioribus delictis riservati alla Congregazione per la Dottrina della Fede, Periodica 91 (2002), s. 309.

${ }^{87}$ Normy, de gravioribus delictis z 2001 r. do kategorii delicta graviora zaliczały przestępstwa przeciwko sakramentom Eucharystii i pokuty, oraz przestępstwo przeciwko obyczajom, łącznie było to dziesięć przestępstw, uwzględniając oczywiście te dodane później.

${ }^{88}$ D. Cito, La prescrizione in materia penale..., s. 222.

${ }^{89}$ CH.J. Scicluna, dz. cyt., s. 284. 
Kolejna istotna zmiana w kwestii liczby przestępstw zastrzeżonych oraz przedawnienia została wprowadzona w 2010 roku $^{90}$. Zgodnie bowiem $\mathrm{z}$ art. 7 Norm de delictis reservatis z 2010 r. przedawnienie actio criminalis następuje zatem dopiero po upływie dwudziestu lat, a czas ten biegnie od dnia popełnienia przestępstwa lub, jeśli przestępstwo jest permanentne bądź habitualne, od dnia jego ustania. Natomiast w przypadku naruszeń przeciwko szóstemu przykazaniu Dekalogu popełnionych przez duchownego z małoletnim poniżej osiemnastego roku życia, czas przedawnienia zaczyna biec od momentu uzyskania pełnoletniości przez małoletniego. Zasadniczo, zgodnie z Kodeksem prawa kanonicznego, po upływie tego czasu dochodzenie wstępne nie może być wszczęte, a tym samym jego kontynuacja wydaje się nielogiczna. Niemniej jednak Normy de delictis reservatis dają Kongregacji możliwość uchylenia przedawnienia w poszczególnych przypadkach $(\operatorname{art} .7 \$ 1)^{91}$.

Kongregacja Nauki Wiary posiada zatem upoważnienie, aby w poszczególnych przypadkach, uchylić dyspozycje dotyczące okresu przedawnienia. Taka sytuacja stwarza jednak pewne trudności w tym, co się odnosi od pogodzenia fundamentalnych zasad kanonicznego prawa karnego z powyższym uprawnieniem, w sposób szczególny będzie chodziło tutaj o konieczność/możliwość aplikowania wobec oskarżonego niekorzystnych przepisów. To wszystko stwarza poważne trudności odnoszące się do obowiązywania, w konkretnym

\footnotetext{
${ }^{90}$ Zgodnie z Normami de delictis reservatis z 2010 r. do katalogu najcięższych przestępstw zastrzeżonych dla Kongregacji Nauki Wiary należą przestępstwa dotyczące wiary, sakramentów (Eucharystii, pokuty i święceń) oraz obyczajów. Por. Normy de delictis reservatis z 2010 r., art. 1-6.

${ }^{91}$ Ponieważ m.p. Sacramentorum Sanctitatis Tutela z 2001 roku nie posiada charakteru retroaktywnego, $\mathrm{z}$ powodu braku wyraźnej wzmianki o takim charakterze w myśl kan. 9, to na mocy kan. $1313 \$ 2$, oskarżony powinien być sądzony na podstawie ustawy dla niego korzystniejszej. Tak więc owe delicta graviora popełnione przed wejściem w życie m.p. będą osądzane według dyspozycji zawartych w m.p., ale w tym, co dotyczy przedawnienia, należy się zastanowić, która z norm będzie korzystniejsza dla oskarżonego. Niemniej jednak należy pamiętać o prawie Kongregacji do uchylenia przedawnienia.
} 
przypadku, zasady favor rei, która to zasada stanowi część integralną kościelnego dobra publicznego, dla ochrony którego zostały ustanowione przepisy karne ${ }^{92}$.

Byłoby może rzeczą bardziej zrozumiałą, gdyby przynajmniej w przypadku niektórych przestępstw zastosowano zasadę niepodlegania przedawnieniu (zawsze jednakże z zachowaniem lex favorabilior). Przynajmniej uniknęłoby się w ten sposób potencjalnej dyskryminacji in peius $\mathrm{w}$ odniesieniu do niektórych podmiotów. W przeciwnym razie łatwo może dojść do rozpowszechnienia się wrażenia, że władza jest stosowana w sposób arbitralny, niezależnie od faktu, że decyzja była podyktowana chęcią zaradzenia w sposób skuteczny bardzo poważnym i gorszącym sytuacjom ${ }^{93}$.

\section{Przedawnienie $w$ ramach odpowiedzialności cywilnej i dyscyplinarnej}

\subsection{Skarga o naprawienie szkód}

Omówione powyżej uwolnienie od roszczeń o charakterze karnym nie oznacza jednak uwolnienia się od roszczeń i konsekwencji o charakterze cywilnym i/lub dyscyplinarnym z tytułu popełnionego przestępstwa. Przedawnieniu nie ulega bowiem, ani samo przestępstwo, ani fakt wymierzenia/deklarowania kary. W obydwu przypadkach mamy do czynienia $\mathrm{z}$ faktami historycznymi, które nie ulegają przedawnieniu ${ }^{94}$. Należy zatem pamiętać o tym, że naruszenia będące przestępstwami powodują lub mogą powodować także inne, pozakarne, skutki. Będzie tutaj mowa o ewentualnych skutkach cywilnych (w postaci skargi o naprawienie szkód) i dyscyplinarnych (przykładowo w postaci wydalenia $\mathrm{z}$ instytutu zakonnego).

\footnotetext{
${ }^{92}$ D. Ciтo, La prescrizione in materia penale..., s. 232.

${ }^{93}$ Tamże, s. 211.

${ }^{94}$ Por. M. Myrcha, dz. cyt., s. 764-765. Warto w tym miejscu zauważyć, że większość przeszkód i nieregularności do przyjęcia i wykonywania święceń, to właśnie przestępstwa kanoniczne, zob. KPK/1983, kan. 1041 i 1044. Nigdzie się jednak nie wspomina, aby takie nieregularności czy przeszkody ulegały przedawnieniu.
} 
Jeżeli chodzi o ewentualne przedawnienie skargi o naprawienie szkód (actio ad damna reparanda), Kodeks prawa kanonicznego z 1983 roku przewiduje możliwość przedawnienia actio criminalis (kan. 1362) i actio poenalis (kan. 1363), ale nie zawiera żadnej dyspozycji dotyczącej przedawnienia się actio ad damna reparanda nie tylko $\mathrm{z}$ tytułu przestępstwa, ale w ogóle z tytułu jakiegokolwiek aktu nielegalnego, o którym mowa w kan. $128^{95}$. Innymi słowy, w odniesieniu do przedawnienia actio ad damna reparanda należy mieć na uwadze to, co się przewiduje w kan. 197-199. Otóż kan. 197 odsyła w tej sprawie, zgodnie zresztą z kan. 22, do ustawodawstwa cywilnego danego kraju, postanawiając, że Kościół w kwestii przedawnienia przyjmuje zasady przewidziane w ustawodawstwie cywilnym danego kraju ${ }^{96}$. Wydaje się jednak, że także w kwestii przedawnienia actio ad damna reparanda w Kościele powinny zostać wprowadzone stosowne zapisy, które regulowałyby tę sprawę. Jest to tym bardziej uzasadnione, jeśli weźmie się pod uwagę, że Kościół przewiduje przecież sprawę naprawienia szkód, czy to na etapie przedprocesowym ${ }^{97}$, czy procesowym ${ }^{98}$. Być może byłoby lepiej, gdyby także i w tym - jakże ważnym przedmiocie - Kościół przewidział stosowne dyspozycje postanawiając przykładowo, że: „Prawo do wniesienia skargi o naprawienie szkód powstałych $w$ wyniku popełnionego przestępstwa ulega przedawnieniu zgodnie z zasadami przewidzianymi dla przedawnienia skargi kryminalnej"99. Jak zauważa C. Papale, miałoby to pozytywne uzasadnienie szczególnie $\mathrm{w}$ odniesieniu do najcięższych przestępstw zaliczanych do kategorii delicta reservata według Norm de delictis

\footnotetext{
${ }^{95}$ Zagadnienie to zostało już przeze mnie omówione w publikacji D. BorEK, Przestępstwa zastrzeżone dla Kongregacji Nauki Wary (Normy materialne i procesowe), Tarnów 2019, s. 228-229. Wydaje się jednak konieczne poruszenie tych kwestii także i w obecnym artykule, ze względu na integralne powiązanie omawianych problemów.

${ }^{96}$ KPK/1983, kan. 197.

${ }^{97} \mathrm{KPK} / 1983$, kan. $1718 \S 4$.

${ }^{98}$ KPK/1983, kan. 1341; 1729-1731.

${ }^{99}$ C. Papale, Il processo penale canonico. Commento al Codice di Diritto Canonico. Libro VII, Parte IV, Città del Vaticano 2012, s. 182.
} 
reservatis z 2010 roku, zgodnie z którymi przedawnienie actio criminalis następuje po upływie 20 lat, $\mathrm{z}$ zachowaniem prawa Kongregacji do uchylenia tegoż terminu ${ }^{100}$. Według wspomnianego wyżej autora wniesienie skargi o naprawienie szkód z tytułu któregoś z przestępstw zastrzeżonych dla Kongregacji Nauki Wiary może nastąpić nie tylko w ciągu owych dwudziestu lat ${ }^{101}$, ale także i po upływie tego terminu, o ile oczywiście Kongregacja skorzysta z przysługującego jej uprawnienia do uchylenia przedawnienia. Proponowane rozwiązanie zdaje się być bardziej korzystne dla strony poszkodowanej, gdyż w obecnej sytuacji prawnej, gdyby osoba poszkodowana nie wniosła skargi o naprawienie szkód w czasie przewidzianym przez prawo cywilne danego kraju, po upływie terminów przewidzianych w tymże prawie nie może wnieść takiej skargi ani na forum państwowym, ani na forum kanoniczym ${ }^{102}$.

\subsection{Wydalenie $\mathrm{z}$ instytutu zakonnego}

Popełnienie określonych przestępstw powoduje także zaistnienie innych skutków oprócz karnych. Przykładowo z tytułu przestępstwa polegającego na usiłowaniu zawarcia małżeństwa przez duchownego, oprócz skutku w postaci kary suspensy latae sententiae, sprawca również automatycznie - traci urząd (kan. $194 \$ 1$, n. 3) oraz zaciąga nieregularność do wykonywania przyjętych święceń (kan. $1044 \$ 1$, n. 3). Przedawnienie actio criminalis i poenalis nie oznacza utraty możliwości ogłoszenia wspominanych wyżej efektów, dotyczących utraty urzędu i nieregularności. Jako przykład można tutaj podać deklarację Papieskiej Rady d.s. Interpretacji Tekstów Ustaw z 1997 roku, gdzie nawiązano właśnie do nieregularności ex delicto, a nie do kan. 1335, aby zadeklarować niezdolność duchownych, którzy

\footnotetext{
${ }^{100}$ Normy de delictis reservatis z 2010 r., art. $7 \$ 1-2$.

${ }^{101}$ Licząc oczywiście od daty popełnienia przestępstwa, a w przypadku przestępstwa molestowania małoletnich od daty, kiedy taki małoletni ukończy osiemnasty rok życia. Normy de delictis reservatis z 2010 r., art. $7 \$ 2$.

${ }^{102}$ C. PApale, dz. cyt., s. 182. Por. D. Borek, Przestępstwa zastrzeżone dla Kongregacji Nauki Wary..., s. 228-229
} 
usiłowali zawrzeć małżeństwo, do sprawowania świętych posług niezależnie od suspensy latae sententiae ${ }^{103}$.

Ponadto przedawnienie, o którym mowa w kan. 1362 i 1363, nie ma zastosowania także i w odniesieniu do wydalenia z instytutu zakonnego. Warto zauważyć, że przyczyny będące powodem wydalenia, zarówno ipso iure jak i ab homine, to jednocześnie przestępstwa kanoniczne. Pośród przyczyn wydalenia ipso iure, w kan. 694 przewiduje się bowiem notoryczne odstąpienie od wiary katolickiej oraz zawarcie małżeństwa lub usiłowanie zawarcia małżeństwa, chociażby tylko cywilnego, oraz bezprawne opuszczenie domu zakonnego przez dwanaście miesięcy bez przerwy ${ }^{104}$. W pierwszym z przypadków mamy do czynienia z przestępstwem, o którym mowa w kan. 1364, natomiast $\mathrm{w}$ drugim $\mathrm{z}$ przestępstwem $\mathrm{z}$ kan. 1394, $\mathrm{w}$ ostatnim ewentualnie $\mathrm{z}$ przestępstwem z kan. 1371. Z kolei zgodnie $\mathrm{z}$ kan. 695 następujące naruszenia będą jednocześnie przestępstwami kanonicznymi: zabójstwo, porwanie lub zatrzymanie siłą lub podstępem (kan. 1397); aborcja (kan. 1398); oraz inne naruszenia przeciwko szóstemu przykazaniu Dekalogu, jeśli spełniają kryteria określone w kan. 1395 \$1-2. Także wśród przyczyn wydalenia ab homine fakultatywnego, zgodnie

\footnotetext{
${ }^{103}$ Wspomniana deklaracja stanowi odpowiedź na pytanie, czy wolno wiernemu lub grupie wiernych prosić, dla słusznej przyczyny, o sprawowanie sakramentów lub sakramentaliów przez duchownego, który usiłował zawrzeć małżeństwo i tym samym podlega suspensie wiążącej mocą samego prawa, która jednak nie została deklarowana (kan. 1335). Według odpowiedzi, takie działanie jest całkowicie nieuprawnione z kilku powodów. Po pierwsze ma tutaj miejsce automatyczna nieprawidłowość w odniesieniu do wykonywania przyjętych święceń (kan. $1044 \$ 1$, n. 3). Po drugie brak słusznej i uzasadnionej przyczyny, z powodu obiektywnej niezdatności do pełnienia posługi. W związku z powyższym, żaden wierny nie ma prawa prosić o udzielenie sakramentów duchownych, którzy zostali wydaleni ze stanu duchownego, niezależnie od tego, czy zawarli małżeństwo czy też nie. Pontificio Consiglio per i Testi Legislativi, Dichiarazione circa la celebrazione dei sacramenti da parte dei sacerdoti che hanno attentato il matrimonio, 19 maggio 1997, Communicationes 29 (1997), s. 17-18.

${ }^{104}$ KPK/1983, kan. 694. Zob. także Franciscus, Litterae apostolicae m.p. Communis Vita, 19.04.2019 r., w: http://www.vatican.va/content/francesco/la/motu_proprio/ documents/papa-francesco-motu-proprio-20190319_communis-vita.html.
} 
z kan. $996 \$ 1$, są naruszenia, które mogą wyczerpywać znamiona określone w prawie kanonicznym przestępstw, albo w każdym razie te $\mathrm{z}$ kan. $1399^{105}$.

Jak zatem można zauważyć, przyczyny leżące u podstaw wydalenia $\mathrm{z}$ instytutu zakonnego to jednocześnie przestępstwa kanoniczne. Nie oznacza to jednak, że w odniesieniu do reguł obowiązujących w przypadku przyczyn i procedury wydalenia $\mathrm{z}$ instytutu zakonnego automatyczne i całościowe zastosowanie będą miały reguły obowiązujące w przypadku wymiaru kar w sensie ścisłym, w tym także dyspozycje dotyczące przedawnienia ścigania i wykonania podjętych decyzji. Bowiem w przypadku wydalenia $\mathrm{z}$ instytutu zakonnego nie mamy do czynienia $\mathrm{z}$ karą $\mathrm{w}$ sensie ścisłym ani z procesem karnym. Tak naprawdę to wydalenie $\mathrm{z}$ instytutu zakonnego jest procedurą sui generis administracyjną, a nie procesem karnym, czy to na drodze administracyjnej, czy sądowej ${ }^{106}$. Mając jednak na uwadze kryteria, jakie znajdują się u podstaw przedawnienia karnego, być może należałby pomyśleć o wprowadzeniu instytucji przedawnienia także w odniesieniu do wydalenia $\mathrm{z}$ instytutu zakonnego. Skoro bowiem, zgodnie z ogólnymi zasadami, przedawnienie jest przewidziane nawet w przypadku najcięższych przestępstw, to tym bardziej należałoby mówić o ewentualnym przedawnieniu w przypadku naruszeń dyscypliny zakonnej, za które przewidziana jest dimissio. Oczywiście takie dostosowanie instytucji przedawnienia - mutatis mutandis - do spraw związanych $\mathrm{z}$ wydaleniem $\mathrm{z}$ instytutu zakonnego powinno być dokonane $z$ uwzględnieniem wszystkich elementów specyficznych, jak chociażby tego, że w przypadku wydalenia ipso iure nie można mówić o ewentualnym przedawnieniu deklarowania takiego faktu, ponieważ prawne wydalenie, ze wszystkimi skutkami, następuje już

\footnotetext{
${ }^{105}$ Szerzej na temat ewentualnych konsekwencji karnych związanych z przyczynami wydalenia z instytutu zakonnego, zob. D. Borek, Wydalenie z instytutu zakonnego $w$ świetle aktualnie obowiązującego kanonicznego prawa karnego, Tarnów 2016.

${ }^{106}$ Por. D. Borek, La dimissione dei religiosi a norma del can. 694 del Codex del 1983: è una pena espiatoria latae sententiae?, Commentarium pro Religiosis et Missionariis 81 (2000), n. I-II, s. 94-95.
} 
w momencie zaistnienia określonej w prawie przyczyny. W takich przypadkach owa późniejsza deklaracja nie posiada charakteru konstytutywnego, ale jedynie deklaratywny odnośnie do skutków, które już zaistniały w momencie popełnienia naruszeń będących przyczyną wydalenia ipso iure ${ }^{107}$.

\section{Wnioski}

Popełnienie naruszeń, które Kościół uznał za przestępstwa kanoniczne, pociąga lub może pociągać za sobą różne skutki i to nie tylko w odniesieniu do sprawcy tychże naruszeń. Pomiędzy tymi skutkami znajduje się m.in. prawo ścigania karnego oraz wykonania kary. Ponadto prawo do naprawienia szkód powstałych z popełnionego przestępstwa oraz prawo zastosowania procedury wydalenia $\mathrm{z}$ instytutu zakonnego.

W pierwszej kolejności, skutki spowodowane przestępstwem występują na płaszczyźnie kanonicznego prawa karnego - materialnego i formalnego. W sposób szczególny będzie tutaj chodziło o powstanie prawa ścigania (actio criminalis), a następnie ewentualnie prawa wykonania kary (actio ad poenam exsequendam). Wspomniane prawo, $z$ różnych względów, m.in. natury procesowej, jest jednak ograniczone w czasie. Innymi słowy, po upływnie określonego w prawie czasu, ustaje możliwość ścigania za popełnione przestępstwo, a więc wszczęcia procesu karnego, kontynuowania go i ewentualnie wykonania wymierzonej kary. Zasady te dotyczą zarówno kar ferendae sententiae, jak i latae sententiae oraz tych przestępstw, które zostały zastrzeżone dla Kongregacji Nauki Wiary. Abstrahując od ewentualnej dyskusji dotyczącej czasokresów przedawnienia, wydaje się konieczne uzupełnienie luki w prawie dotyczącej instytucji przerwy i zawieszenia biegu przedawnienia actio criminalis i poenalis. Ustawodawca kodeksowy z 1983 roku, przewidując przedawnienie ścigania karnego, nie uwzględnił jednak odnośnych dyspozycji mówiących o przerwie i/ lub zawieszeniu biegu przedawnienia. Wprowadzenie w tej kwestii

\footnotetext{
${ }^{107}$ Por. KPK/1983, kan. $694 \$ 2 ; 701$.
} 
odnośnych dyspozycji rozwiałoby istniejące do tej pory wątpliwości dotyczące biegu przedawnienia w czasie trwania procesu karnego.

Jak zostało zauważone, naruszenia będące przestępstwami kanonicznymi powodują lub mogą powodować także inne, pozakarne skutki cywilne i/lub dyscyplinarne.

W pierwszym z przypadków będzie chodziło o szkody spowodowane przestępstwem i związaną z tym skargę o naprawienie szkód (actio ad damna reparanda). Należy podkreślić, że prawo kanoniczne nie przewiduje wprost przedawnienia skargi o naprawienie szkód powstałych z przestępstwa, ale odsyła do norm ogólnych i tym samym do prawa cywilnego obowiązującego na terytorium danego kraju. Niemniej jednak zasadnym wydaje się być postulat, według którego także i w przypadku przedawnienia skargi o naprawienie szkód powstałych z przestępstwa należałoby wprowadzić te same zasady, co w przypadku przedawnienia ścigania przestępstw, szczególnie w przypadku przestępstw należących do kategorii delicta graviora.

Także w sytuacji wydalenia $\mathrm{z}$ instytutu zakonnego nic się nie mówi na temat ewentualnego przedawnienia się takiej możliwości. Wydaje się, że zasady dotyczące przedawnienia actio criminalis i poenalis nie mogą mieć zastosowania do instytucji wydalenia $\mathrm{z}$ instytutu zakonnego przede wszystkim z tego względu, że wydalenie nie jest karą w sensie ścisłym, a procedura wydalenia nie jest - w konsekwencji procesem karnym. Biorąc jednak pod uwagę zasady, chociażby te natury procesowej, jakie leżą u podstaw instytucji przedawnienia karnego, należałoby pomyśleć także o wprowadzeniu przedawnienia - mutatis mutandis - w odniesieniu do wydalenia $\mathrm{z}$ instytutu zakonnego.

\section{The prescription of penal actions and operations resulting from canon delicts violations}

Violations constituting canon delicts incur certain legal effects, both penal and non penal. Among strictly penal effects one can find a possibility to call a perpetrator to account. In order to do this The Canon Law Code of 1983 classifies two types of actions connected with the committed delict: 
a criminal action (actio criminalis) and an action to execute a penalty (action ad poenam exsequendam), or a penal action. A violation which is a crime may result in other, non penal effects such as an action to repair the damage caused by the crime (actio ad damna reparanda), a declaration of an obstacle to ordination, or a dismissal from a religious institute. The prescription, which is the subject of this article, is thus connected with different possible effects incurred by a violation constituting a canon delict.

Keeping all those possible consequences of violations constituting canon delicts, it seems legitimate to establish the matter of the prescription. Trying to find the answers to these questions, the author tries to focus on the following issues: 1. Prescription. 1.1. Introductory issues. 1.2. Principal terms and elements. 2. Prescription within penal responsibility 2.1. Imposing and executing a penalty. 2.2. Declaring a penalty. 2.3. Delicts reserved to the Congregation for the Doctrine of the Faith. 3. Prescription within civil and disciplinary responsibility 3.1. Action to repair damage. 3.2. Dismissal from a religious institute.

SŁOWA KLUCZOWE: przestępstwo; kanoniczne prawo karne; kanoniczny proces karny; skarga karna; skarga o naprawienie szkód; przedawnienie; przestępstwa zarezerwowane Kongregacji Nauki Wiary; cywilna odpowiedzialność; dyscyplinarna odpowiedzialność, wydalenie z instytutu

KEYwORDs: Delict; penal canon law; penal canon process; criminal action; action to execute a penalty; prescription; delicts reserved to the Congregation for the Doctrine of the Faith; civil responsibility; disciplinary responsibility; dismissal from the institute

\section{Nota o AUTORZE}

O. DR hab. Dariusz Borek, Prof. UCzelni - należy do prowincji pw. św. Józefa w Polsce Zakonu Braci Najświętszej Maryi Panny z Góry Karmel (Karmelici). Od 2001 roku jest zatrudniony na Wydziale Prawa Kanonicznego Uniwersytetu Kardynała Stefana Wyszyńskiego w Warszawie. Jest autorem różnych publikacji - monografii i artykułów - szczególnie z zakresu kanonicznego prawa karnego. 